\title{
PENERAPAN PIDANA TERHADAP ANGGOTA POLRI YANG MELAKUKAN TINDAK PIDANA PENCURIAN DENGAN KEKERASAN MENGGUNAKAN SENJATA API (Studi Putusan Nomor : 42/Pid.B/2016/PN.Swl dan Putusan Nomor : 43/Pid.B/2016/PN.Swl)
}

\author{
Bevi Hendro ${ }^{1}$, Iyah Faniyah ${ }^{2}$, Adhi Wibowo ${ }^{3}$ \\ ${ }^{1}$ Pascasarjana Ilmu Hukum, Universitas Ekasakti \\ Email : bevihendro@gmail.com \\ ${ }^{2}$ Pascasarjana Ilmu Hukum, Universitas Ekasakti \\ Email : iyahfaniyah01@gmail.com \\ ${ }^{3}$ Pascasarjana Ilmu Hukum, Universitas Ekasakti \\ Email : wibowo.adhi@ rocketmail.com
}

\begin{abstract}
Based on Article 363 paragraph (1) of the 4th Criminal Code, people who commit theft carried out by 2 persons together or more are threatened with a maximum imprisonment of 7 years. Therefore the Case of Crime of Theft with Violence using Firearms based on Decision Number: 42 / Pid.B / 2016 / PN.Swl and Decision Number: 43 / Pid.B / 2016 / PN. 1 (one) year and 10 (ten) months, charge the Defendant to pay a court fee of Rp. 5,000.00 (five thousand rupiah) and pay attention to Article 365 paragraph (2) of the 2nd Book of the Criminal Law. The specification of this research is descriptive analytical. While the approach method used is normative juridical. The data source used is secondary data. The data obtained were analyzed qualitatively and presented descriptively analytically. Based on the results of research and discussion, it can be concluded; First, the application of a criminal against a member of the National Police who commits a crime of theft with violence using firearms in the decision number: 42 / Pid.B / 2016 / PN.Swl and Decision Number: 43 / Pid.B / 2016 / PN.Swl are: Article 365 paragraph (2) of the 2nd Criminal Code, namely: "A maximum sentence of twelve years imprisonment, is imposed, (2nd) if the act is carried out by two people together or more", with the elements of criminal charges of the Prosecutor General, namely: Whose element of goods; Take something; Elements that are entirely or partially owned by others; Elements With the intention to be owned illegally; Elements That are carried out preceded by, accompanied by, or followed by violence or threats of violence, against a person with a view to preparing or facilitating theft, or in the event of being caught red-handed, to allow themselves to escape or other participants, or to retain possession of stolen property; Elements are carried out by 2 (two) people or more together. Secondly, the consideration of the judge in the application of the criminal to a member of the police who committed a crime of theft with violence using firearms in the decision Number: 42 / Pid.B / 2016 / PN.Swl and Decision Number: 43 / Pid.B / 2016 / PN. Swl are: juridical considerations: prosecutor's indictment, witness testimony, defendant's testimony, evidence. considerations that are non-juridical: the background of the defendant and the religion or belief held by the defendant, the physical and spiritual condition of the defendant, as a result of the defendant's actions.
\end{abstract}

Keywords: Anggota Polri, Tindak Pidana Pencurian, dan Kekerasan Menggunakan Senjata Api. 


\section{PENDAHULUAN}

Negara Indonesia adalah Negara Hukum berdasarkan Pasal 1 ayat (3) Undangundang Dasar Negara Republik Indonesia Tahun 1945. Hukum berfungsi untuk mengatur hubungan antara manusia yang satu dengan manusia lainnya dan hubungan antara manusia dan negara agar segala sesuatunya berjalan dengan tertib. Oleh karena itu, tujuan hukum adalah untuk mencapai kedamaian dengan mewujudkan kepastian hukum dan keadilan di dalam masyarakat. Kepastian hukum menghendaki adanya perumusan kaedah-kaedah dalam peraturan perundang-undangan yang jelas dan tegas.

Undang-undang Nomor 8 Tahun 1981 tentang Kitab Undang-Undang Hukum Acara Pidana (KUHAP) telah mengatur secara lebih rinci tentang Kedudukan, Peranan dan Tugas Kepolisian Negara Republik Indonesia dalam kaitannya dengan proses pidana sebagai penyelidik dan penyidik serta melaksanakan koordinasi dan pengawasan terhadap Penyidik Pegawai Negeri Sipil tertentu yang diberi wewenang khusus oleh undang-undang. Pasal 1 angka (1) KUHAP disebutkan pengertian penyidik adalah Pejabat Polisi Negara Republik Indonesia atau Pejabat Pegawai Negeri Sipil tertentu yang diberi wewenang khusus oleh undang-undang untuk melakukan penyidikan.

Berdasarkan Undang-undang Nomor 2

Tahun 2002 tentang Kepolisian Negara Republik Indonesia telah menetapkan fungsi, tujuan dan tugas Kepolisian Negara Republik Indonesia. Dalam Pasal 2 Undang-undang Nomor 2 Tahun 2002 tersebut dinyatakan bahwa:

"Fungsi Kepolisian Negara Republik Indonesia adalah salah satu fungsi pemerintah Negara di bidang pemeliharaan keamanan dan ketertiban masyarakat, penegakan hukum, perlindungan, pengayoman dan pelayanan kepada masyarakat".

Disadari akan tugas dan wewenang Kepolisian yang sedemikian berat dan bersentuhan langsung dengan perlindungan jiwa maka pemerintah dan aparat penegak hukum mengembangkan jangkauan usaha seluas mungkin dan melengkapi petugas penegak hukum dengan berbagai jenis senjata api dan amunisi yang memungkinkan penggunaan kekerasan dan senjata api secara luas, namun disertai usaha memperkuat pengendalian pengguna persenjataan agar tidak mematikan atau melukai. Namun dalam penggunaan senjata api oleh Anggota Polri masih banyak penyalahgunaan.

Penyalahgunaan penggunaan senjata api ini ada yang dilakukan dalam rangka melaksanakan tugas dan ada yang dilakukan diluar konteks pelaksanaan tugas. ${ }^{1}$

Bila kita melihat dari pemberitaan yang ada di media belakangan ini atau yang terjadi dilingkungan masyarakat, banyak sekali penyimpangan penyimpangan perilaku Polisi

1 Parker Thomas and Carter David, Penyimpangan Polisi (terjemahan Police Deviance), Cipta Manunggal. Jakarta, 1999, hlm 57. 
seperti penggunaan kekuatan yang sewenang wenang. Hukum dapat mencapai tujuannya apabila dapat menyeimbangkan antara kepastian hukum dan keadilan, atau keserasian, antara kepastian yang bersifat umum atau obyektif dan penerapan keadilan secara khusus yang bersifat subyektif. ${ }^{2}$ Salah satu permasalahan hukum yaitu kejahatan yang sangat meresahkan masyarakat adalah kejahatan dengan menggunakan senjata api. Senjata api ini, seperti yang disampaikan oleh Tom A. Warlow, merupakan senjata yang dapat dibawa kemana-mana. ${ }^{3}$

Padahal diketahui bahwa anggota Kepolisian sebelum diberi senjata api harus memenuhi berbagai macam syarat-syarat tertentu, seperti yang telah diatur dalam Pasal 6 ayat (1) Peraturan Kepala Kepolisian Republik Indonesia Nomor Polisi 4 Tahun 2007 tentang Tata Cara Pemeriksaan Psikologi Bagi Calon Pemegang Senjata Api Organik Kepolisian Negara Republik Indonesia dan Non-Organik Tentara Nasional Indonesia/Kepolisian Negara Republik Indonesia, yaitu metode yang digunakan untuk mengungkap aspek-aspek Psikologi sebagaimana dimaksud dalam Pasal 3 ayat (1) adalah:

1. Psikotes;

2 Soedjono Dirdjosisworo, Pengantar Ilmu Hukum, PT. Raja Grafindo Persada, Jakarta, 2012, hlm 18.

3 Josias Simon Runturambi dan Atin Sri Pujiastuti, Senjata Api dan Penanganan Tindak Kriminal, Yayasan Pustaka Obor Indonesia, Jakarta, 2015, hlm 1.
2. Wawancara;

3. Observasi; dan

4. Dokumentasi.

Kepolisian Negara Republik Indonesia (Polri) merupakan lembaga yang menjalankan tugas kepolisian sebagai profesi, maka membawa konsekuensi adanya kode etik profesi maupun peraturan disiplin yang harus dipatuhi oleh setiap Anggota Polri.

Pelanggaran kode etik profesi maupun peraturan disiplin kepolisian bagi Anggota Polri merupakan suatu hal yang takterelakkan, menginggat dalam pelaksanaan tugas kepolisian akan selalu berhadapan dengan hak dan kewajiban warga negara secara langsung. Anggota Polri yang melaksanakan tugas dan wewenangnya yang melanggar kode etik profesi atau peraturan disiplin Kepolisian, maka Anggota Polri tersebut harus mempertanggungjawabkan perbuatannya dihadapan sidang komisi kode etik.

Ketika terjadi suatu penyalahgunaan penggunaan senjata api yang dilakukan personil Polri, terdapat beberapa kebijakan yang diambil pimpinan Polri, mulai dari kebijakan reaktif yang memerintahkan bahwa senjata yang dipinjam pakaikan kepada semua jajaran dilapangan harus segera ditarik dan disimpan.

Kepolisian Negara Republik Indonesia ataupun sidang disiplin Kepolisian Republik Indonesia Ketentuan yang mengatur perilaku Anggota Polri yang dituangkan dalam bentuk Kode Etik Profesi Polri maupun peraturan 
disiplin merupakan pedoman moral atau perilaku yang harus senantiasa dipegang teguh oleh Snggota Polri dalam menjalankan tugasnya sehari-hari. Namun, ada juga anggota Polri yang berperilaku yang menyimpang, sehingga melanggar Kode Etik Polri, peraturan disiplin bahkan melanggar ketentuan hukum pidana.

Tindak pidana yang dilakukan oleh setiap Anggota Polri akan diproses sesuai dengan ketentuan hukum pidana yang berlaku. Yaitu diproses dan diajukan di dalam lingkup peradilan umum. Hal ini sesuai dengan ketentuan yang diatur dalam pasal 7 ayat (4) TAP MPR NO. VII/MPR/2000 tentang peran Tentara Nasional Indonesia dan Peran Kepolisian Negara Republik Indonesia sebagai berikut: "Anggota Kepolisian Negara Republik Indonesia tunduk pada kekuasaan peradilan umum". Perkara Pidana Nomor: 42/Pid.B/2016.PN.SWL dan Perkara Pidana Nomor: 43/Pid.B/2016/PN.SWL telah diputus oleh Majelis Hakim Pengadilan Negeri Sawahlunto dengan Amar Putusan sebagai berikut: Menyatakan Terdakwa Yopi Utama terbukti bersalah dan meyakinkan telah melakukan tindak pidana pencurian dengan kekerasan sebagaimana diatur dalam ke I (satu) Primer Pasal 365 ayat (2) ke (2) KUHP, Subsider Pasal 363 ayat (1) ke (4) KUHP dan ke II (kedua) Pasal 1 ayat (1) Undang-undang Darurat Republik Indonesia Nomor 12 Tahun 1951; Menyatakan Terdakwa Meky Putra dan Richard Ishak Hutahaean terbukti bersalah dan meyakinkan telah melakukan Tindak Pidana Pencurian dengan Kekerasan sebagaimana diatur dalam ke I (satu) Primer Pasal 365 ayat (2) ke (2) KUHP, Subsider Pasal 363 ayat (1) ke (4) KUHP; Menjatuhkan pidana penjara terhadap Terdakwa Yopi Utama selama 1 tahun 10 bulan dan dikurangi selama menjalani hukuman; Menjatuhkan pidana penjara terhadap Terdakwa Meky Putra dan Richard Ishak Hutahaean selama 1 tahun 8 bulan dan dikurangi selama menjalani hukuman serta Membebankan biaya perkara sebesar Rp.2.500,- (dua ribu lima ratus rupiah).

Segala bentuk penyimpangan oleh aparat Kepolisian tentunya tidak akan terjadi apabila masing-masing Anggota Kepolisian sadar akan posisinya sebagai pelindung, penganyom serta sebagai penegak hukum yang paling dekat dengan masyarakat. Di Kota Sawahlunto sendiri masih kerap terjadi tindakan penyimpangan oleh Anggota Kepolisian.

Berdasarkan latar belakang pemikiran di atas, penulis tertarik untuk mengetahui dan menganalisis "Penerapan Pidana Terhadap Anggota Polri Yang Melakukan Tindak Pidana Pencurian Dengan Kekerasan Menggunakan Senjata Api (Studi Putusan Nomor : 42/Pid.B/2016/PN.Swl dan Putusan Nomor : 43/Pid.B/2016/PN.Swl)". 


\section{METODE PENELITIAN}

Untuk menjawab permasalahan seperti yang telah diuraikan diatas, maka dalam melaksanakan penelitian yang berfungsi sebagai acuan, sehingga hasil dari penelitian dapat menemui sasaran dan dapat dipertanggung jawabkan.

Pendekatan yang digunakan dalam penelitian ini adalah pendekatan yuridis normatif Pendekatan yuridis normatif yang dilakukan menitiberatkan pada data kepustakaan dengan menginventarisasikan bahan-bahan kepustakaan mengenai Penerapan Pidana terhadap Anggota Polri yang melakukan Tindak Pidana Pencurian dengan Kekerasan menggunakan Senjata Api.

Data primer dan data sekunder yang telah terkumpul akan dianalisis secara kualitatif dan disajikan dalam bentuk deskriptif kualitatif, yaitu hanya memaparkan dengan menggunakan kata-kata dan kalimatkalimat, jadi tidak berupa angka-angka.

\section{HASIL PENELITIAN}

Hasil penelitian tentang putusan Nomor 42/PID.B/2016/PN.SWL dan putusan nomor 43/PID.B/2016/PN.SWL tentang penyalahgunaan senjata api oleh anggota polri.

Perkara Nomor : 42/PID.B/2016/PN.

SWL Pengadilan Negeri Sawahlunto yang mengadili perkara pidana dengan acara pemeriksaan biasa dalam tingkat pertama telah menjatuhkan putusan sebagai berikut dalam perkara Terdakwa Yopi Utama Panggilan Yopi bersama-sama dengan Saksi Meky Putra Panggilan Meky Bin Zulherman, Saksi Richard Ishak Hutahaean Panggilan Richard, dan Saksi Mario Efrizal Candra Panggilan Rio Alias Kubu (penuntutan terpisah) secara bersama-sama pada hari Senin tanggal 09 Mei 2016 sekitar Jam 11.50 Wib. atau pada suatu waktu dalam tahun 2016 bertempat di halaman parkiran depan Bank Syariah Mandiri Desa Moaro Kalaban Kecamatan Silungkang Kota Sawahlunto atau pada suatu tempat yang masih termasuk dalam daerah hukum Pengadilan Negeri Sawahlunto, mengambil sesuatu barang, yang seluruhnya atau sebagian kepunyaan orang lain, dengan maksud untuk dimiliki secara melawan hukum, yang didahului, disertai atau diikuti dengan kekerasan atau ancaman kekerasan, terhadap orang dengan maksud untuk mempersiapkan atau mempermudah pencurian, atau dalam hal tertangkap tangan, untuk memungkinkan melarikan diri sendiri atau peserta lainnya, atau untuk tetap menguasai barang yang dicuri, yang dilakukan oleh dua orang atau lebih dengan bersekutu, berupa uang tunai sejumlah \pm Rp.160.000.000,-(seratus enam puluh juta rupiah) atau setidak-tidaknya sebesar Rp.166.855.000,- (seratus enam puluh enam juta delapan ratus lima puluh lima ribu rupiah) milik saksi Silvia Antika Panggilan Sil, perbuatan mana dilakukan terdakwa dengan cara-cara sebagai berikut: 
Bahwa selanjutnya terdakwa menghubungi saksi Mario untuk datang ke Muara Kalaban pada hari Senin tanggal 9 Mei 2016 dan saksi Mario menyetujuinya;

Bahwa uang yang telah diambil dari saksi korban kemudian oleh terdakwa sebanyak Rp.40.000.000,- (empat puluh juta rupiah) diserahkan kepada saksi Mario sesuai dengan kesepakatan semula sedangkan sisanya yang merupakan bagian terdakwa dan bagian saksi Meky dan saksi Richard disimpan oleh terdakwa dirumahnya.

Bahwa kemudian dilakukan penangkapan terhadap saksi Meky, saksi Richard, selanjutnya dilakukan penangkapan terdakwa dan saksi Rio

Bahwa akibat perbuatan Terdakwa Yopi Utama Panggilan. Yopi bersama-sama dengan Saksi Meky Putra, Saksi Richard Ishak Hutahaean dan Saksi Mario Efrizal Candra mengakibatkan saksi Silvia Panggilan Sil mengalami kerugian sebesar Rp.166.855.000,-- (seratus enam puluh enam juta delapan ratus lima puluh lima ribu rupiah).

Terdakwa Yopi Utama Panggilan Yopi telah didakwa dengan dakwaan yang berbentuk subsidairitas yaitu Dakwaan Primair dan Dakwaan Subsidair melakukan tindak pidana "pencurian dengan kekerasan dalam keadaan memberatkan" dan "tanpa hak menguasai, membawa dan memperguna-kan senjata api".
Menimbang, bahwa Terdakwa telah didakwa oleh Penuntut Umum dengan dakwaan gabungan, maka Majelis Hakim terlebih dahulu mempertimbangkan dakwaan kesatu primair sebagaimana diatur dalam Pasal 365 ayat (2) ke-2 Kitab Undang-Undang Hukum Pidana.

Maka dari itu Pengadilan Negeri Sawahlunto memutuskan Perkara No 42/PID.B/2016/PN.SWL;

1. Menyatakan terdakwa Yopi Utama panggilan Yopi, terbukti secara sah dan meyakinkan bersalah melakukan tindak pidana "pencurian dengan kekerasan dalam keadaan memberatkan" dan "tanpa hak menguasai, membawa dan mempergunakan senjata api";

2. Menjatuhkan pidana kepada Terdakwa oleh karena itu dengan pidana penjara selama 1 (satu) tahun dan 10 (sepuluh) bulan;

3. Menetapkan masa penangkapan dan penahanan yang telah dijalani Terdakwa dikurangkan seluruhnya dari pidana yang dijatuhkan;

4. Memerintahkan Terdakwa tetap ditahan;

5. Menetapkan barang bukti.

6. Membebankan kepada Terdakwa membayar biaya perkara sejumlah Rp5.000,00 (lima ribu rupiah);

Perkara Nomor : 43/PID.B/2016/PN.

SWL Pengadilan Negeri Sawahlunto yang mengadili perkara pidana dengan acara pemeriksaan biasa dalam tingkat pertama 
telah menjatuhkan putusan sebagai berikut dalam perkara Para Terdakwa Meky Putra Pgl. Meky Bin Zulherman, Terdakwa Richard Ishak Hutahaean Pgl. Richard, Terdakwa Mario Efrizal Candra Pgl. Rio Alias Kubu, dan Saksi Yopi Utama Pgl. Yopi (penuntutan secara terpisah) secara bersama-sama pada hari Senin tanggal 09 Mei 2016 sekitar jam 11.50 Wib. atau pada suatu waktu dalam tahun 2016 bertempat di halaman parkiran depan Bank Syariah Mandiri Desa Moaro Kalaban Kecamatan Silungkang Kota Sawahlunto atau pada suatu tempat yang masih termasuk dalam daerah hukum Pengadilan Negeri Sawahlunto, mengambil sesuatu barang, yang seluruhnya atau sebagian kepunyaan orang lain, dengan maksud untuk dimiliki secara melawan hukum, yang didahului, disertai atau diikuti dengan kekerasan atau ancaman kekerasan, terhadap orang dengan maksud untuk mempersiapkan atau mempermudah pencurian, atau dalam hal tertangkap tangan, untuk memungkinkan melarikan diri sendiri atau peserta lainnya, atau untuk tetap menguasai barang yang dicuri, yang dilakukan oleh dua orang atau lebih dengan bersekutu, berupa uang tunai sejumlah \pm Rp.160.000.000,-(seratus enam puluh juta rupiah) atau setidak-tidaknya sebesar Rp.166.855.000,- (seratus enam puluh enam juta delapan ratus lima puluh lima ribu rupiah) milik saksi Silvia Antika Pgl. Sil, perbuatan mana dilakukan para terdakwa dengan cara-cara sebagai berikut :

Bahwa selanjutnya saksi Yopi Utama menghubungi terdakwa III untuk datang ke Muara Kalaban pada hari Senin tanggal 9 Mei 2016 dan terdakwa III menyetujuinya;

Bahwa uang yang telah diambil dari saksi korban kemudian oleh saksi Yopi Utama sebanyak Rp.40.000.000,- (empat puluh juta rupiah) diserahkan kepada terdakwa III sesuai dengan kesepakatan semula sedangkan sisanya yang merupakan bagian saksi Yopi Utama dan terdakwa I serta terdakwa II disimpan oleh saksi Yopi Utama dirumahnya.

Bahwa kemudian dilakukan penangkapan terhadap terdakwa I dan terdakwa II, selanjutnya dilakukan penangkapan saksi Yopi Utama dan terdakwa III.

Bahwa akibat perbuatan Terdakwa I, terdakwa II dan terdakwaIII serta saksi Yopi Utama mengakibatkan saksi SILVIA Pgl. SIL mengalami kerugian sebesar Rp.166.855.000,- (seratus enam puluh enam juta delapan ratus lima puluh lima ribu rupiah).

Terdakwa Meky Putra Panggilan Meky Bin Zulherman, Richard Ishak Hutahaean Panggilan Richard dan Mario Efrizal Candra Panggilan Rio Alias Kubu telah didakwa dengan dakwaan yang berbentuk subsidairitas yaitu Dakwaan Primair dan Dakwaan Subsidair melakukan tindak pidana "pencurian dengan kekerasan dalam keadaan 
memberatkan" dan "tanpa hak menguasai, membawa dan mempergunakan senjata api";.

Menimbang, bahwa Para Terdakwa telah didakwa oleh Penuntut Umum dengan dakwaan subsideritas, maka Majelis Hakim terlebih dahulu mempertimbangkan dakwaan primair sebagaimana diatur dalam Pasal 365 ayat (2) ke-2 Kitab Undang-Undang Hukum Pidana.

Maka dari itu Pengadilan Negeri Sawahlunto memutuskan Perkara No 43/PID.B/2016/PN.SWL;

1. Menyatakan terdakwa I Meky Putra panggilan Meky bin Zulherman, terdakwa II Richard Ishak Hutahaean panggilan Richard, dan terdakwa III Mario Efrizal Candra panggilan Rio alias Kubu, terbukti secara sah dan meyakinkan bersalah melakukan tindak pidana "pencurian dengan kekerasan dalam keadaan memberatkan";

2. Menjatuhkan pidana kepada Para Terdakwa oleh karena itu dengan pidana penjara masing-masing selama 1 (satu) tahun dan 8 (delapan) bulan;

3. Menetapkan masa penangkapan dan penahanan yang telah dijalani Para Terdakwa dikurangkan seluruhnya dari pidana yang dijatuhkan;

4. Menetapkan Para Terdakwa tetap ditahan;

5. Menetapkan barang bukti.

6. Membebankan kepada Para Terdakwa membayar biaya perkara masing-masing sejumlah Rp5.000,00 (lima ribu rupiah);

\section{PEMBAHASAN}

Penerapan Pidana terhadap Anggota Polri yang melakukan Tindak Pidana Pencurian dengan Kekerasan menggunakan Senjata Api pada Putusan Nomor: 42/Pid.B/ 2016/PN.Swl dan Putusan Nomor: 43/Pid.B /2016/PN.Swl

Penerapan pidana terhadap Anggota Polri yang Melakukan Tindak Pidana Pencurian dengan Kekerasan menggunakan Senjata Api pada Putusan Nomor : 42/Pid.B/2016/PN.Swl dan Putusan Nomor : 43/Pid.B/2016/PN.Swl yaitu sebagai berikut:

1. Pasal 365 ayat (2) ke 2 KUHP, yaitu "Hukuman penjara selama-lamanya dua belas tahun, dijatuhkan, (ke-2) jika perbuatan itu dilakukan oleh dua orang bersama-sama atau lebih.

2. Pasal 1 ayat (1) Undang-undang Darurat Nomor 12 Tahun 1951 tentang Mengubah "Ordonnantietijdelijke Bijzondere Strafbepalingen" (Stbl. 1948 Nomor 17) dan Undang-undang Dahulu Nomor 8 Tahun 1948, yaitu: Barang siapa, yang tanpa hak memasukkan ke Indonesia membuat, menerima, mencoba memperoleh, menyerahkan atau mencoba menyerahkan, menguasai, membawa, mempunyai persediaan padanya atau mempunyai dalam miliknya, menyimpan, mengangkut, menyembunyikan, mempergunakan, atau mengeluarkan dari Indonesia sesuatu senjata api, amunisi atau sesuatu bahan peledak, dihukum dengan hukuman mati atau hukuman penjara 
seumur hidup atau hukuman penjara sementara setinggi-tingginya dua puluh tahun.

Unsur-unsur pidana yang terdapat dalam Pasal 365 ayat (2) ke-2 KUHP pada Putusan Nomor: 42/Pid.B/2016/PN.Swl dan Putusan Nomor: 43/Pid.B/2016/PN.Swl adalah sebagai berikut:

1. Barang Siapa.

2. Unsur Mengambil sesuatu barang.

3. Unsur Yang seluruhnya atau sebagian kepunyaan orang lain.

4. Unsur Dengan maksud untuk dimiliki secara melawan hokum.

5. Unsur Yang dilakukan dengan didahului, disertai, atau diikuti dengan kekerasan atau ancaman kekerasan, terhadap orang dengan maksud untuk mempersiapkan atau mempermudah pencurian, atau dalam hal tertangkap tangan, untuk memungkinkan melarikan diri sendiri atau peserta lainnya, atau untuk tetap menguasai barang yang dicuri.

6. Unsur dilakukan oleh 2 (dua) orang atau lebih secara bersama-sama.

Menurut sistem Kitab Undang-Undang Hukum Pidana Indonesia yang dapat menjadi subyek hukum pidana ialah natuurlijk person atau manusia. Hal itu dapat dilihat dalam tiap-tiap pasal KUHP, Buku II dan Buku III, sebagian besar kaidah-kaidah hukum pidana yang KUHP dimulai dengan kata "barang siapa" sebagai terjemahan dari bahasa belanda. $^{4}$

Dalam hal penentuan subyek hukum dalam suatu ketentuan perundangan tentunya mempunyai persyaratan yang diatur dalam sistem hukum yang berlaku tidak kecuali di Indonesia. Berpijak pada perspektif ketentuan hukum pidana (penal), seseorang dapat dikenai sanksi pidana sebagai subyek hukum atas suatu peraturan perundangan didasari dengan norma tidak tertulis "geen straf zonder schuld; actus nonfacit reum nisi mens sir rea (tidak ada pidana jika tidak ada kesalahan)". Dasar ini terkait erat dengan kemampuan bertanggungjawab atas perbuatan yang telah dilakukannya, setelah itu dikaji menggunakan parameter adanya kesalahan (liability based on mistake) dan kemampuan bertanggungjawab (criminal responsibility). ${ }^{5}$

Mengenai subyek atau pelaku pelaku perbuatan pidana menurut Barda Nawawi Arief "secara umum hukum hanya mengakui orang sebagai pelaku, sedangkan mengenai pertanggungjawaban pidana dianut asas kesalahan, yang berarti untuk dapat menjatuhan pidana kepada pembuat delik, disamping harus memenuhi unsur-unsur

\footnotetext{
${ }^{4}$ Zainal Abidin Farid, Hukum Pidana I, Sinar Grafika, Jakarta, 2007, hlm. 395

5 Muhammad Rustamaji dan Dewi Gunawati, MOOT COURT, Membedah Peradilan Pidana dalam Kelas Pendidikan Hukum Progresif, cetakan pertama, CV Mevi Caraka, Surakarta, 2011, hlm. 132.
} 
rumusan delik juga harus ada kesalahan dan kemampuan bertanggungjawab. ${ }^{6}$

Dalam berbagai cara atau teknik perumusan delik diuraikan perbuatan melawan hukum yang dilarang atau yang diperintahkan untuk dilakukan dan kepada barang siapa yang melanggarnya atau tidak mentaatinya diancam dengan pidana maksimum. Teknik yang paling lazim digunakan untuk merumuskan delik menurut Jonkers ialah dengan menerangkan atau menguraikannya. Dari keterangan atau uraian itu dapatlah diketahui unsur-unsur delik atau cara yang kedua ialah pasal undang-undang tertentu menguraikan unsur-unsur delik lalu ditambahkan kualifikasi atau sifat dan gelar delik tersebut. ${ }^{7}$

Apabila melihat dari Putusan Nomor: 42/Pid.B/2016/PN.Swl dan Nomor: 43/Pid.B/2016/PN.Swl, yang menjadi pertimbangan hakim yaitu:

1. Kesalahan dari pelaku hal pertama yang menjadi pertimbangan hakim sebelum menjatuhkan putusan.

2. Tidak ditemukannya alasan pemaaf dan pembenar sebagai alasan penghapusan pidana.

3. Barang bukti yang ada dalam persidangan. Dalam hal ini hakim telah didukung oleh dua alat bukti yang sah sebagaimana

${ }^{6}$ Barda Nawawi Arief, Bunga Rampai Kebijakan Hukum Pidana, Citra Aditya Bakti, Bandung, 2002, hlm. 85.

${ }^{7}$ Zainal Abidin Farid, 2007. Op. Cit., hlm. 346. diterapkan dalam Pasal 183 juncto Pasal 185 KUHAP.

\section{Pertimbangan Hakim dalam Penerapan Pidana terhadap Anggota Polri yang melakukan Tindak Pidana Pencurian dengan Kekerasan menggunakan Senjata Api pada Putusan Nomor: 42/Pid.B/ 2016/PN.Swl dan Putusan Nomor: 43/Pid. B/2016/PN.Swl}

Sesuai dengan proses persidangan yang berlaku di Indonesia seorang Hakim tidak dapat menjatuhkan putusan kepada seorang terdakwa dalam suatu kasus sebelum terdakwa menjalani proses pembuktian di dalam persidangan. Dalam proses pembuktian di dalam persidangan akan ditemukan faktafakta hukum yang kemudian akan dijadikan pertimbangan Hakim dalam menjatuhkan putusan.

Proses pembuktian dalam persidangan sangat penting karena melalui proses itulah fakta-fakta hukum terkait tindak pidana yang terjadi akan terungkap. Dengan telah ditemukannya bukti-bukti dan faktor-faktor lain dalam persidangan, maka Hakim akan memiliki dasar pertimbangan dalam mengambil keputusan.

Hakim menjatuhkan putusan kepada terdakwa berdasarkan pada peraturan perundang-undangan yang berlaku di Indonesia. Penjatuhan pidana oleh Hakim dalam perkara yang satu dengan perkara yang lainnya yang pada pokoknya sama terkadang putusan yang dijatuhkan tidak sama. Hakim tidak hanya mempertimbangan sesuai dengan 
apa yang ada dalam peraturan/bersifat teoritis tetapi juga memperhatikan hal yang sifatnya konkret.

Pada penyelenggaraan musyawarah hakim guna menyusun putusan, majelis Hakim harus mempertimbangkan keseluruhan dokumen yang syahih dan keseluruhan fakta yang terungkap dalam persidangan.

Pengesampingan analisir di luar fakta persidangan demikian sejatinya digunakan untuk memperoleh sebuah putusan yang berkeadilan, berkepastian dan mempunyai kebermanfaatan setelah dijatuhkan atas diri terdakwa nantinya. Oleh karenanya pencermatan terhadap Surat Dakwaan, Nota Keberatan, Alat Bukti dan segala sesuatu yang terungkap serta terbukti di persidangan, Surat Tuntutan (Requisitoir), Nota Pembelaan (Pleidooi) maupun Replik dan Duplik, mutlak dilakukan oleh majelis Hakim untuk menghasilkan dokumen putusan.

Hakim dalam menjatuhkan putusan mempertimbangkan banyak hal, dimana sebagian besar Hakim di Indonesia menggunakan jenis pertimbangan yang sifatnya yuridis maupun non yuridis.

Putusan yang dijatuhkan Hakim Pengadilan Negeri Sawahlunto sudah mencerminkan keadilan karena putusan tersebut diambil setelah melihat fakta-fakta hukum yang terungkap dalam persidangan. Banyak hal yang menjadi pertimbangan bagi Hakim dalam menjatuhkan putusan seperti surat dakwaan, surat tuntutan, alat bukti, barang bukti. Hal-hal yang meringankan terdakwa menjadi alasan bagi Hakim untuk untuk meringankan pidana yang dijatuhkan kepada terdakwa. Dalam setiap putusan yang akan dijatuhkan Hakim akan melihat rasa keadilan agar putusan yang dijatuhkan nantinya memberikan keadilan bagi terdakwa.

\section{PENUTUP}

Penerapan pidana terhadap Oknum Anggota Polri yang melakukan Tindak Pidana Pencurian dengan Kekerasan menggunakan Senjata Api pada putusan Nomor: 42/Pid.B/2016/PN.Swl dan Putusan Nomor: 43/Pid.B/2016/PN.Swl adalah: Pasal 365 ayat (2) ke 2 KUHP, yaitu: "Hukuman penjara selama-lamanya dua belas tahun, dijatuhkan, (ke-2) jika perbuatan itu dilakukan oleh dua orang bersama-sama atau lebih", dengan unsur-unsur pidana dakwaan Penuntut Umum, yaitu: Unsur barang siapa; Mengambil sesuatu barang; Unsur Yang seluruhnya atau sebagian kepunyaan orang lain; Unsur Dengan maksud untuk dimiliki secara melawan hukum; Unsur Yang dilakukan dengan didahului, disertai, atau diikuti dengan kekerasan atau ancaman kekerasan, terhadap orang dengan maksud untuk mempersiapkan atau mempermudah pencurian, atau dalam hal tertangkap tangan, untuk memungkinkan melarikan diri sendiri atau peserta lainnya, atau untuk tetap menguasai barang yang dicuri; Unsur dilakukan oleh 2 (dua) orang atau lebih secara bersama-sama. 
Pertimbangan hakim dalam penerapan pidana terhadap oknum anggota polri yang melakukan tindak pidana pencurian dengan kekerasan menggunakan senjata api pada putusan Nomor: 42/Pid.B/2016/PN.Swl dan Putusan Nomor: 43/Pid.B/2016/PN.Swl adalah: pertimbangan yang bersifat yuridis: dakwaan jaksa penuntut umum, keterangan saksi, keterangan terdakwa, barang-barang bukti. pertimbangan yang bersifat non yuridis: latar belakang terdakwa serta agama atau keyakinan yang dianut terdakwa, kondisi jasmani maupun rohani terdakwa, akibat perbuatan terdakwa.

\section{DAFTAR PUSTAKA}

\section{Buku-buku}

Adami Chazawi, Pelajaran Hukum Pidana I, PT. Raja Grafindo, Jakarta, 2010.

Barda Nawawi Arief, Bunga Rampai Kebijakan Hukum Pidana, Citra Aditya Bakti, Bandung, 2002.

Josias Simon Runturambi dan Atin Sri Pujiastuti, Senjata Api dan Penanganan Tindak Kriminal, Yayasan Pustaka Obor Indonesia, Jakarta, 2015.

Muhammad Rustamaji dan Dewi Gunawati, MOOT COURT, Membedah Peradilan Pidana dalam Kelas Pendidikan Hukum Progresif, cetakan pertama, CV Mevi Caraka, Surakarta, 2011.

Parker Thomas and Carter David, Penyimpangan Polisi (terjemahan Police Deviance), Cipta Manunggal. Jakarta, 1999.
Soedjono Dirdjosisworo, Pengantar Ilmu Hukum, PT. Raja Grafindo Persada, Jakarta, 2012.

Soerjono Soekanto dan Mustafa Abdullah., Sosiologi Hukum Dalam Masyarakat, CV Raja Wali, Jakarta, 1987.

Zainal Abidin Farid, Hukum Pidana I, Sinar Grafika, Jakarta, 2007.

\section{Perundang-undangan}

Undang-Undang Dasar Negara Republik Indonesia Tahun 1945;

Undang-undang Nomor 1 Tahun 1946 tentang Peraturan Hukum Pidana (KUHP);

Undang-undang Republik Indonesia Nomor 8 Tahun 1948 tentang Mencabut Peraturan Dewan Pertahanan Negara Nomor 14 dan Menetapkan Peraturan tentang Pendaftaran dan Pemberian Izin Pemakaian Senjata Api;

Undang-undang Darurat Nomor 12 Tahun 1951 tentang Kepemilikan Senjata Api Illegal;

Undang-undang Nomor 12 Tahun 1952 tentang Senjata Api;

Undang-undang Nomor 8 Tahun 1981 tentang Hukum Acara Pidana (KUHAP);

Undang-undang Nomor 2 Tahun 2002 tentang Kepolisian Negara Republik Indonesia;

Undang-undang Nomor 48 Tahun 2009 tentang Kekuasaan Kehakiman;

Undang-undang Nomor 49 Tahun 2009 tentang Perubahan Kedua Undangundang Nomor 2 Tahun 1986 tentang Peradilan Umum.;

Peraturan Pemerintah Nomor 1 Tahun 2003 tentang Peraturan Disiplin Anggota Kepolisian Negara Republik Indonesia;

Peraturan Pemerintah Nomor 2 Tahun 2003 tentang Disiplin Polri;

Peraturan Pemerintah Nomor 58 Tahun 2010 Perubahan Atas Peraturan Pemerintah 
Nomor 27 Tahun 1983 tentang Pelaksanaan Kitab Undang-Undang Hukum Acara Pidana;

Peraturan Kapolri Nomor 1 Tahun 2009 tentang Penggunaan Kekuatan dalam Tindakan Kepolisian untuk Menegakkan Hukum dan Menciptakan Keamanan Serta Ketertiban;

Peraturan Kapolri Nomor 8 Tahun 2009 tentang Implementasi Prinsip dan Standar Hak Asasi Manusia dalam Penyelenggaraan Tugas Kepolisian Negara Republik Indonesia;

Peraturan Kapolri Nomor 11 Tahun 2017 tentang Perijinan, Pengawasan dan Pengendalian Senpi;

Peraturan Kapolri Nomor 14 Tahun 2011 tentang Kode Etik Kepolisian Negara Republik Indonesia;

Putusan Nomor: 42/Pid.B/2016/PN.Swl.

Putusan Nomor: 43/Pid.B/2016/PN.Swl.

Artikel \& Website

http://kbbi.web.id/.

https://jurnalsrigunting.wordpress.com/20

11/10/12/penggunaan-senpi-dalamtugas-kepolisian-suatu-tinjauanetika-profesi-kepolisian/ 